\title{
Birth in Sydney
}

\section{Lisa Featherstone}

Imagine giving birth in a bark hut with no assistance. Or in a comfortable middle class home, with family and a midwife or doctor to help. Or perhaps in an intimidating hospital, with stirrups and an obstetrician providing stark comfort or again, in a birthing centre, surrounded by supportive women. Mothers in Sydney have given birth in a multitude of settings, from traditional Aboriginal environs, to the most technologically advanced hospital. Giving birth may have been easy, moving, joyful, a celebration of life. Or it may have been fraught with difficulties, even disaster.

Childbirth is not merely a natural event, worked by the body, but an event mediated by culture and social expectations. ${ }^{1}$ How women understand and experience birth was and is shaped by the physical birth itself, but also by understandings of femininity, womanhood and maternity, and by our responses to newborns, children and the concept of family. In different time frames and places, childbirth can be experienced very differently by women. There are a wide variety of understandings of birth for women across the centuries.

\section{Birthing with grandmother's law}

Childbirth in Sydney began with the women's business of indigenous mothers. Women's 'birthing' was not merely the labour and birth of an infant, but part of a wider symbolic process, covering the land and country, the Dreaming and the Law. ${ }^{2}$ We do not now have a good understanding of traditional Aboriginal birthing processes and the Grandmother's Law that governed it. When we consider white records of indigenous births, we must remember that they are interpreted through cultural difference, and may not provide a full or accurate view of traditional birthing. Further, men wrote many of the earliest reports, and they would not have access to the deep symbolic rituals of reproduction.

In early 1791, Lieutenant David Collins wrote the first account of the birth of an indigenous baby. This is an important record of traditional birthing practices among the Eora people. Only women were present at the labour of War-re-weer. Though they did not manually assist with the delivery, the women provided crucial moral and ritual support, plus a measure of pain relief (cold water poured on the abdomen). After the birth, the Europeans cut the umbilical cord - this was probably a shock to the mother, who may have preferred to ease into a period of separation. After delivery the child and placenta, the mother was 'smoked' with herbs to aid her recovery, and indeed she quickly returned to her usual duties, with her baby by her side. ${ }^{3}$ 


\section{The white woman's labour}

The labour of War-re-weer was closely tied to traditional customs and ritual, but the first European women who delivered babies in Australia were not so fortunate. European obstetric care in Australia was very basic. In the early years of convict settlement, naval surgeons treated women, but as free settlers began to arrive, there were no adequate health care provisions for them. ${ }^{4}$ For most of the nineteenth century, there were few public or private resources devoted to childbirth, with only the destitute receiving institutionalised medical care. In Sydney, the Benevolent Society Asylum (which stood near the present Central Railway station) provided obstetric services to women who were 'penniless and friendless, and must perforce have been confined in the streets. ${ }^{5}$

In Sydney in 1870, around two-thirds of confinements were attended by midwives whose abilities depended on shared knowledge, practical experience and care as most had no professional qualifications. ${ }^{6}$ Women were cared for during their confinement by midwives, Aboriginal women, neighbours, family or occasionally the local doctor. Childbirth was a test of endurance, largely faced with the support of other women, and an uncomplicated labour was painful but rewarding. A difficult or prolonged labour, however, could take be nightmarish. From midcentury, some women were given chloroform or ether for pain relief, while others relied on alcohol and prayer or simply suffered. Doctors used forceps for difficult deliveries, but touching the genitals with hands or instruments increased the risk of infection and the deadly puerperal fever (septicaemia).

\section{Medical control of childbirth}

By the late nineteenth century, there was a marked change, with the ideal confinement performed under medical control and surveillance. Underpinning this shift was a profound and pervasive pronatalism. From the 1880s, population growth was seen as the key to the establishment and maintenance of the colonies. It became increasingly important to save maternal and infant lives, and childbirth was therefore medicalised. Childbirth came to be seen as an injury or crisis, rather than a natural life event. As Sir James Graham suggested in 1904,

the pregnant woman, from the professional point of view, during her terms of pregnancy, is practically on the sick list... the border line between the normal and the pathological is very narrow, indeed. ${ }^{7}$

All pregnancy and childbirth, whether complicated or not, was linked with sickness and ill health: the risk of death in childbed was reflected back onto the whole process.

In 1897, 558 out of a total of 12,009 registered births in Sydney took place in public hospitals. All of the mothers were destitute, and 452 of the children were illegitimate. ${ }^{8}$ Most women still had their babies at home, with the help of a doctor, or if they could not afford this, a midwife, who 
was increasingly likely to be a trained nurse. ${ }^{9}$ This medicalisation changed the process of birthing significantly. Late nineteenth century doctors recommended mothers should labour lying down, ostensibly to conserve the mother's strength. ${ }^{10}$ This assumption depended on a view of the female body as weak, inert and passive. There were practical implications too. The horizontal position acted to slow the labour, and made intervention (in particular from forceps) more likely. ${ }^{11}$

Thus early medical care did not necessarily help mothers. Maternal mortality rates did not fall and indeed in some cases rose. ${ }^{12}$ Rising mortality was a result of medical care: initially through puerperal fever, spread by instruments, and then through the extended use of dangerous surgeries such as the caesarean section. ${ }^{13}$ Nevertheless, women frequently welcomed medical assistance perhaps because of the pain relief a doctor could provide.

We must note here that the majority of Australian women had frequent and relatively unproblematic experiences of childbirth. For a proportion of women, however, confinement could be a dangerous time. In 1898, the statistician TA Coghlan calculated that white women in New South Wales who married at age 25 had a one in 32 lifetime chance of a full term labour resulting in immediate maternal death. This excluded the women who died from post-labour complications. ${ }^{14}$ The most common cause of death was puerperal fever. Other significant causes of death were placenta praevia, when the placenta blocked the birth passage, and puerperal convulsions, most likely caused by high blood pressure. ${ }^{15}$ Class, too, played a role. An undernourished woman might fail to survive a post-partum haemorrhage from which a healthy woman would recover, and vitamin deficiencies could impair her body's ability to labour effectively. ${ }^{16}$ It is perhaps not surprising then that around one third of births presenting at the Benevolent Society were complicated. ${ }^{17}$

\section{Going to hospital}

Increased medical care during confinement, then, did not have the positive impact doctors had hoped. Nevertheless, the demand for hospitals grew. The Women's Hospital (known affectionately as 'Crown Street') was established in 1896, and quickly moved to larger premises. It aimed to treat obstetrics and gynaecological cases amongst the 'poor and necessitous women' of Sydney. Many were treated in their own homes by visiting nurses and midwives, while more difficult cases were seen by medical staff. ${ }^{18}$ In the first decade, the Women's Hospital attended 3891 births, mainly in poverty-stricken homes not conducive to hygiene. Nevertheless, the results were impressive, with the death rate far below the state average. ${ }^{19}$ In northern Sydney, the Sydney Sanitarium at Wahroonga (a private, Seventh Day Adventist hospital) took obstetrics cases from 1903, and the maternity ward expanded in 1915 and again in $1933 .{ }^{20}$

Between 1919 and 1933, births in public hospitals doubled, and increasingly women birthed in private hospitals, rather than at home. ${ }^{21}$ Yet, despite individual successes, death rates for mothers 
remained stubbornly high and maternal mortality was still seen as a 'grave national danger.' ${ }^{22}$ Even the impact of antenatal care, introduced in the 1910s and 1920s, was not great. ${ }^{23}$ Women continued to suffer, with many giving birth without adequate assistance, well into the 1920s and 1930s. ${ }^{24}$ As oral history records, childbirth could be an emotional, physical and financial strain:

Dulcie was born in a back room in a boarding house there. I didn't get to hospital. The others were all born around here. You had the old midwife come in. She was as rough as bags. If you had any money, you'd give her a couple of pounds, or, if not, you'd pay it off. When I had the last one [during World War II], I went to hospital, but I didn't have the fare ... I had to pay that off, too! $!^{25}$

Childbirth could bring hardship, as well as joy.

Clinically, antibiotics proved the major advance, and in the 1940s and 1950s, death rates from puerperal fever dropped markedly. But the birthing experiences of women did not necessarily improve. The use of anaesthetics had become more widespread in the 1930s, but so too had the use of inductions, forceps and other techniques of intervention. ${ }^{26}$ Men were excluded from the delivery room, and mothers and babies were often separated after birth. Up until the 1970s, and even beyond, childbirth in a hospital could be an alienating, dispiriting exercise. ${ }^{27}$

\section{Childbirth and choice}

The 1970s saw a temporary and rather limited movement away from medical control of birth. Women, inspired by the successes of feminism and consumer rights more generally, began to fight to recover 'women-centred' birth experiences. The changes were dramatic, as Sister Rosemary Hambling remembered of her time at Crown Street. In the early 1970s, she said, 'patients conformed as they were not informed'. From this time on, women were encouraged to move about during labour, partners were welcomed into the labour wards, and the environment was made less clinical and more homelike. ${ }^{28}$ Birthing centres emerged as an option for those interested in natural childbirth: the centres were a midpoint between home birth and the hospital.

Since then, attitudes towards childbirth have split noticeably. On one hand, there has continued a strong midwife-driven movement towards women's control over childbirth, with advocates pressing for increased knowledge, empowerment and choice about pregnancy, birth and lactation. ${ }^{29}$ Services have responded by becoming more mother-friendly, and women's networks of midwives, mothers and lactation consultants have flourished. ${ }^{30}$

On the other hand, there has been a steady increase in medicalised, technologically affected births, reflected in the rates of electronic foetal monitoring, induction, epidural anaesthesia and, most noticeably, caesarean section. In 1997, less than 10 per cent of NSW babies were delivered via caesarean section. Since then, the rates have skyrocketed, with 28.1 per cent of mothers delivering by caesarean in 2005. ${ }^{31}$ The rate was highest in private hospitals (35 per cent). ${ }^{32}$ This 
is far above World Health Organisation recommendations, which suggest that caesareans should account for around 10 per cent of all births. Reasons for this increase include obstetricians' fear of litigation and higher numbers of older mothers. It has in part been consumer-driven, with women fearing pain and damage to their babies or themselves. ${ }^{33}$ As the secretary for the NSW Midwives Association suggested, women are 'thinking of it as another option for birth, rather than major abdominal surgery'. ${ }^{34}$ It is representative, ultimately, of an 'emerging sense of crisis around childbirth', as if birth itself can never be uncomplicated or even achievable. ${ }^{35}$ In Sydney in 2008, women in public hospitals can no longer demand caesarean section without a medical reason, but only time will tell if caesarean rates will continue to increase. ${ }^{36}$

In many ways, contemporary obstetricians have framed themselves as providers of 'choice' for women. But this choice has been limited largely to medical options. For instance, the lack of medical liability insurance for independent midwives has largely undermined the home birth movement (in 2005, 0.1 per cent of NSW babies were delivered at home). ${ }^{37}$ Birthing centres at major Sydney hospitals (complete with aromatherapy and spa baths) are advances on the stirrups and shaved genitals of a generation before, but the emphasis is still on institutionalised birth. Education on all of the medical and social facts surrounding birth is crucial. Many Sydney women with private obstetricians choose an elective caesarean for non-medical purposes, but the risks of this must be highlighted. Ethics, as well as the evident risks and rewards, must be seriously considered, as birth-related technologies, such as the uses of surrogacy, gene therapy, in-vitro fertilisation and gamete intra fallopian transfer expand.

\section{Conclusions}

The history of childbirth, then, is one marked by a series of continuities, advances, junctions and setbacks. Yet there is perhaps, underneath it all, a sense of progress. Fewer women die and fewer babies die than did a century ago, and that must be marked as an achievement for both mothers and babies. There is still, however, room for improvement, particularly within indigenous health, with Aboriginal families facing low birth weights, poor maternal health and increased perinatal mortality rates. If health outcomes for Aboriginal people are to improve to first world standards, childbirth would seem a good place to start, in Sydney and beyond.

Lisa Featherstone is a Research Fellow in the Department of Modern History at Macquarie University in Sydney.

1 Ann Oakley, From Here to Maternity: Becoming a Mother, Penguin Books, Middlesex UK, 1979, p 20; Ann Oakley, Women Confined: Towards a Sociology of Childbirth, Martin Robertson, Oxford, 1980, p 7

2 Helen Callaghan, 'Traditional Aboriginal Birthing Practices in Australia: Past and Present', Birth Issues, vol 10, no 3-4, 2001, p 93 
${ }^{3}$ David Collins, An Account of the English Colony of New South Wales (1798), BH Fletcher (ed) Reed Books, Sydney, 1975, vol 1, p 264-65; Patricia Grimshaw et al, Creating a Nation, 1788-1990, McPhee Gribble, Melbourne, 1994, p 7-14

4 John Best, Portraits in Australian Health, MacLennan and Petty, Sydney, 1988, p 20

${ }^{5}$ Report of the Benevolent Society of New South Wales, For the year ending $31^{\text {st }}$ December 1888, Sydney, 1889, p 12

6 John Campbell, 'Early developments in Australian obstetrics', in John Pearn (ed), Pioneer Medicine in Australia, Amphion Press, Brisbane, 1988, p 193

7 Sir James Graham, 'Obstetric nursing with special reference to savage races,' Australasian Nurses Journal, 2, 1904, p 54

8 Milton Lewis, “'Populate or Perish”: Aspects of Infant and Maternal Health in Sydney 1870-1939,' PhD Thesis, Australian National University, 1976, p 228, p 230

${ }^{9}$ Kerreen M Reiger, The disenchantment of the home: Modernising the Australian family, Oxford University Press, Melbourne, 1985, p 84-103

10 TL McMillan, 'On the natural obstetrics of the Aborigines of the New Hebrides', Australasian Medical Gazette, February 1883, p 98

${ }^{11}$ Robbie E Davis-Floyd, Birth as an American Rite of Passage, University of California Press, Berkeley, 1992, p 122

12 James Jamieson, 'Childbirth Mortality in the Australian Colonies,' Australian Medical Journal, 15 October 1887, p 447

${ }^{13}$ Lisa Featherstone, 'The Kindest Cut? The Origins of the Caesarean Section in Australia,' in Marie Porter, Patricia Short and Andrea O'Reilly (eds), Mother Power? Contemporary Feminist Voices, Women's Press, Toronto, 2005

14 TA Coghlan, 'Deaths in Childbirth in New South Wales', Journal of the Royal Statistical Society, 63, 1898, p 528

15 TA Coghlan, The Wealth and Progress of New South Wales, 1900-01, William Applegate Gullick, Sydney, 1902, p 59

${ }^{16}$ Irvine Louden, Death in Childbirth, An International Study of Maternal Care and Maternal Mortality 1800-1950, Clarendon Press, Oxford, 1992, p 45; SE Sanchez, C Zhang and MR Malinow et al, 'Plasma folate, vitamin B12 and homocysteine concentrations in preeclamptic and normotensive Peruvian women,' American Journal of Epidemiology, 153 (5), 2001, pp 474-480

${ }^{17}$ Calculated from Report of the Benevolent Society, 1898, Sydney, 1899, p 29

${ }^{18}$ Crown Street Centenary Committee, The Women's Hospital (Crown Street) 1893-1983, Sydney, Crown Street Centenary Committee, 1994, p 9

19 Crown Street Centenary Committee, The Women's Hospital (Crown Street) 1893-1983, Sydney, Crown Street Centenary Committee, 1994, p 12

${ }^{20}$ Arthur N Patrick, The San: 100 Years of Christian Caring 1903-2003, Sydney Adventist Hospital, Sydney, 2003, p 205 
${ }^{21}$ Milton Lewis, 'Hospitalisation for Childbirth in Sydney, 1870-1939: The Modern Maternity Hospital and Improvement in the Health of Women', Journal of the Royal Australian Historical Society, vol 66, part 3, December 1980, p 199

22 Commonwealth Parliamentary Papers, Report of the Royal Commission on Health together with Appendices, HJ Green, Government Printer, Melbourne, 1926, p 32

${ }^{23}$ Lisa Featherstone, 'Surveying the Mother: The Rise of Antenatal Care in Early Twentieth-Century Australia', Limina, 10, 2004

24 Janet McCalman, 'Hard Cases Make Bad History: Doctors and Childbirth Between the Wars', in Delys Bird, Wendy Ware and Terri-ann White (eds), Future Imaginings: Sexualities and Genders in the New Millennium, University of Western Australia Press, Perth, p 71-86

${ }^{25}$ Interview with Phyllis Acland, in Wendy Lowenstein, Weevils in the Flour: An oral record of the 1930s Depression in Australia, Scribe, Melbourne, 1978, p 22

${ }^{26}$ Kerreen M Reiger, The disenchantment of the home: Modernising the Australian family, Oxford University Press, Melbourne, 1985, pp 99-101

${ }^{27}$ Kerreen M Reiger, Our Bodies, Our Babies, The Forgotten Women's Movement, Melbourne University Press, Melbourne, 2001, p 1, p 16

28 'Rosemary Hambling Remembers' in Crown Street Centenary Committee, The Women's Hospital (Crown Street) 1893-1983, Sydney, Crown Street Centenary Committee, 1994, p 80

${ }^{29}$ Kerreen M Reiger, Our Bodies, Our Babies, The Forgotten Women's Movement, Melbourne University Press, Melbourne, 2001

${ }^{30}$ Kerreen Reiger, 'A neo-liberal quickstep: contradictions in Australian maternity policy', Health Sociology Review, vol 15 no 4, October 2006, pp 333-35

${ }^{31}$ NSW Department of Health, 'New South Wales Mothers and Babies 2005', NSW Public Health Bulletin, 2007, vol 16, no S-4, p 10

32 NSW Department of Health, 'NSW report reveals alarming rise in caesareans', www.health.nsw.gov/news/2006/20060113_01.html

${ }^{33}$ Dr Tony Frumar, obstetrician at the Prince of Wales Private Hospital, Sydney, cited in Danielle Teutsch, 'Caesarean rate alarms doctors', Sydney Morning Herald, 7 July 2002

34 Julie Robotham, ‘NSW hospitals move to block caesarean option’, The Age, 7 April 2007

${ }^{35}$ Kerreen M Reiger and Rhea Dempsey, 'Performing birth in a culture of fear: an embodied crisis of late modernity’, Health Sociology Review, vol 15 no 4, October 2006, pp 364-73

36 Julie Robotham, 'NSW hospitals move to block caesarean option', The Age, 7 April 2007

${ }^{37}$ NSW Department of Health, 'New South Wales Mothers and Babies 2005', NSW Public Health Bulletin, 2007, vol 18, no S-1, p 22 